\title{
A Note from the Author
}

The purpose of this study of Milton's poetry and the religious tradition is to interpret Milton in an age increasingly skeptical, in a culture dominated by the assumptions of the natural and historical sciences and by the illusions of progress and enlightenment. Its implicit thesis is that man's search for God and his struggle to overcome the material forces and prejudices that impede this search transcend in value all other human efforts. Unless "amid all the changes and chances of this mortal life, our hearts are surely fixed where true joys are to be found," life here lacks any true and final purpose or meaning. In the light of this truth I have undertaken to study some of the themes and symbols in Milton's poetry. To speak more precisely, I have attempted to trace the course of certain ideas, symbols, and themes and to show how these are embodied and are transformed in Comus, Lycidas, Paradise Lost, and Samson Agonistes.

Without tradition, which need not be static and which in any case played a vital part in the dissemination and preservation of Gospel truth, the Christian faith and church would never have reached Milton and the modern world. Tradition can be a constant witness for the Lord and His living Word, in darkness as well as in light. Christianity and tradition are really inseparable. Even when he rejects traditional ceremonies and dogmas, Milton's poetry is best understood with reference to tradition, to which it is indebted.

Drawing upon Scripture, Milton compared truth to a "streaming fountain": "if her waters flow not in a perpetual progression, they 
sicken into a muddy pool of conformity and tradition." He scorned and feared conformity: "I fear this yoke of outward conformity hath left a slavish print upon our necks." In Michael's preview of history in Paradise Lost, tradition is linked with superstition and coercion as an anti-Christian aberration, a mystery of iniquity, which corrupts the pure doctrine and story of Holy Scripture, upon which Milton, as a true Protestant, relies. The pure tradition of Scripture as interpreted by Protestants and shaped by his own intense convictions was Milton's ideal guide.

The subject is treated not as an academic problem of literary history nor as an abstract concept or occasion for sophisticated literary criticism but rather as an opportunity to show in the light of tradition the permanent spiritual and moral value of Milton's poetry. Without any loss of objectivity, this value is at all times kept firmly in mind-not in a utilitarian or dogmatic fashion but rather as a means of inviting the reader to share in a genuine understanding and appreciation of the poetry.

The kinship of poetry and religion should be emphasized. As has been said, poetry is a chief means by which religious realism is achieved. Without the aid of poetry, religious mystery can hardly be expressed. Poetry, which both enchants and informs, addresses its rhythmic and symbolic speech to regions of the mind which are inaccessible to argument.

In the present state of society the need of a genuine spiritual and religious renaissance should be apparent. Every civilization, and, not withstanding its astonishing technical achievements, even the current one-every civilization is corrupt, because each is the product of the human heart, which makes self, rather than God or what Julian Huxley calls the Sacred Reality, the center of existence. Thus every culture bears within itself the seeds of its own dissolution. Our mechanical triumphs and even our physical comforts may be the insidious foes of spiritual health.

In this tortured but complacent century, when materialism is rampant and when humanism, become gray and grim, seems to be "the last defence of the genteel tradition against chaos," we urgently need the wisest counsel, with true religion and the clear voice of conscience as our faithful guides. Some may return, spiritually if not literally, to the worship of what Evelyn Underhill calls the Universal Church: "her penitence, her supplication, her invulnerable confidence, her adoring delight in the splendour of God." In the words of Benjamin Jowett, some may repair to the example and the teaching of Christ, xiv 


\begin{abstract}
A Note from the Author
as to a fountain of light, "purging away the mist of eighteen centuries, which have insensibly gathered over the Christian world, yea, and over our own hearts also." It is my earnest hope that the voice and the message of Milton as here interpreted, echoing out of the distant past across the tumult of human hopes and fears, will even now to alien ears speak of things invisible to mortal sight and once more reveal how we may so pass through things temporal that we finally lose not the things eternal.
\end{abstract}


THIS PAGE INTENTIONALLY LEFT BLANK 